\title{
O futuro do Cade
}

\author{
O ex-presidente do Conselho Administrativo de Defesa Eco- \\ nômica, analisa os rumos do organismo que presidiu durante \\ oito anos, e entra no debate sobre o anteprojeto de criação da \\ agência de defesa do consumidor e da concorrência.
}

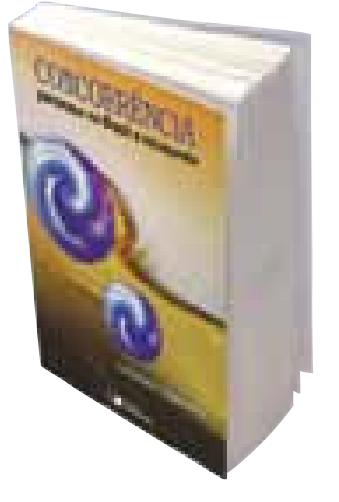

Concorrência: panorama no Brasil e no mundo Gesner Oliveira Ed. Saraiva

\section{Por Paulo Furquim de Azevedo UFSCar}

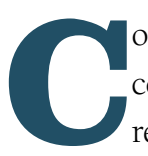
omo seria bom ouvir a história contada por seus próprios atores. Entretanto, infelizmente, nem sempre esses atores têm tempo ou oportunidade de dedicarem-se à narrativa. O livro de Gesner Oliveira "Concorrência: panorama no Brasil e no mundo" é uma feliz exceção. Nele o autor trata, essencialmente, do sistema brasileiro de defesa da concorrência, que não só foi por ele presidido por oito anos, como também colocado na ordem do dia da política pública e das estratégias empresariais. Durante o período em que Gesner presidiu o Cade, o organismo cresceu em número de julgados, em produtividade, em recursos disponíveis e, em especial, em notoriedade.

O livro está estruturado em sete capítulos, cuja espinha dorsal é a discussão do modelo de desenho institucional da defesa da concorrência no Brasil. Em síntese, o livro reúne quatro temas centrais para a definição da configuração do sistema brasileiro de defesa da concorrência, que povoaram as discussões sobre o assunto na década de 90: a) as particularidades de uma economia emergente (Capítulo 1); b) a crescente integração comercial, no âmbito do Mercosul e da OMC (Capítulos 2 e 3); c) a definição de competências entre a agência de defesa da concorrência e as agências regulatórias setoriais, que tiveram grande impulso após a privatização dos serviços de utilidade pública (Capítulos 4 e 5); e d) a relação entre investimento estrangeiro e defesa da concorrência (Capítulo 6). Finalmente, o Capítulo 7 reúne os argumentos desenvolvidos nos capítulos anteriores para uma finalidade de ação: uma crítica ao Anteprojeto de Criação de Agência de Defesa do Consumidor e da Concorrência e a proposta de um modelo alternativo.

A experiência e a formação teórica qualifica Gesner como observador diferenciado do sistema brasileiro de defesa da concorrência. Entretanto, o que aqui predomina não é o autor-observador, mas o autor-ator com o propósito de modificação de seu objeto de análise. No Capítulo 4, o livro alcança maior sofisticação quando a defesa da concorrência incorpora sua relação com as agências regulatórias setoriais. São apresentadas cinco possíveis configurações institucionais definidas pelo tipo de regulação e pelo agente responsável por conduzir a regulação. Como passo seguinte, o autor desenvolve os critérios para a escolha da configuração institucional adequada, explorando diversos trade-offs - como o risco de captura, as economias de escala e escopo, e o custo 
burocrático. Conclui-se que é desejável a fusão entre SDE, SEAE e Cade, cujas rotinas administrativas são similares, e indesejável a formação de uma superagência, reunindo as diversas agências regulatórias setoriais, uma vez que o conhecimento específico necessário para cada uma delas reduziria os ganhos da fusão.

No Capítulo 7, o livro atinge o objetivo do autor-ator capaz de convencer o leitor das falhas do Anteprojeto de Criação da Agência de Defesa do Consumidor e da Concorrência. Chama à atenção a preocupação com a história da defesa da concorrência no Brasil. Sua proposta preserva a "Marca Cade". Apesar de cerca de 30 anos de sua existência, a sigla era, no início da década de 1990, desconhecida. A notoriedade veio em casos como os da KolynosColgate e da Ambev, e, também, pelo esforço de Gesner.

Essa notoriedade é fundamental para disciplinar as práticas anticompetitivas que venham a ferir a legislação. Mais interessante que o número de julgados, é a disciplina incutida nos negócios que evitariam práticas possivelmente rejeitadas pelo Cade. Nesse sentido, a notoriedade carrega duas dimensões: a) sua disseminação entre os atores econômicos); e b) a reputação associada à jurisprudência que se desdobra na consistência das decisões e em seu perfil. Essa é uma escolha complexa, pois deve lidar com o trade-off do risco de aprovar uma operação que deveria ser rejeitada e de bloquear outra que deveria ser aceita.

Entre essas duas dimensões, a atuação mais expressiva do Cade foi a disseminação da "cultura da concorrência", o que implica a inclusão da restrição institucional no universo das estratégias empresariais. Além disso, aumentou a consistência das deci- sões com a sofisticação dos argumentos nos votos e pareceres e a elaboração de um referencial de análise das transações.

É importante destacar a queda de intervenção em atos de concentração, o que significa que diminui a restrição às estratégias empresariais e à reestruturação produtiva. Enquanto a visibilidade da defesa da concorrência é positiva, o mesmo não pode ser dito da redução da taxa de intervenção, ou seja, de uma jurisprudência mais permissiva. Não criar obstáculo está associado ao risco de uma prática indesejável. Aprovar tudo, elimina o benefício da defesa da concorrência. Há um grau ótimo de permissão que atenua ambos os riscos. Dados recentes do Cade mostram, todavia, maior preocupação em evitar o bloqueio de uma operação que deveria ter sido aprovada, o que pode indicar uma jurisprudência permissiva.

O livro é referência aos que participam da reestruturação desse sistema. Há, contudo, questões relevantes não aprofundadas. Entre elas, a periodicidade de mandatos, a aplicação de decisão colegiada e as características de enforcement de decisões, sobretudo nos compromissos de desempenho. De qualquer modo, trata dos problemas mais relevantes e polêmicos quando o modelo de agência reguladora está sobre a mesa.

\section{A atuação mais expressiva do Cade foi a disseminação da "cultura da concorrência", o que implica a inclusão da restrição institucional no universo das estratégias empresariais. 99}

